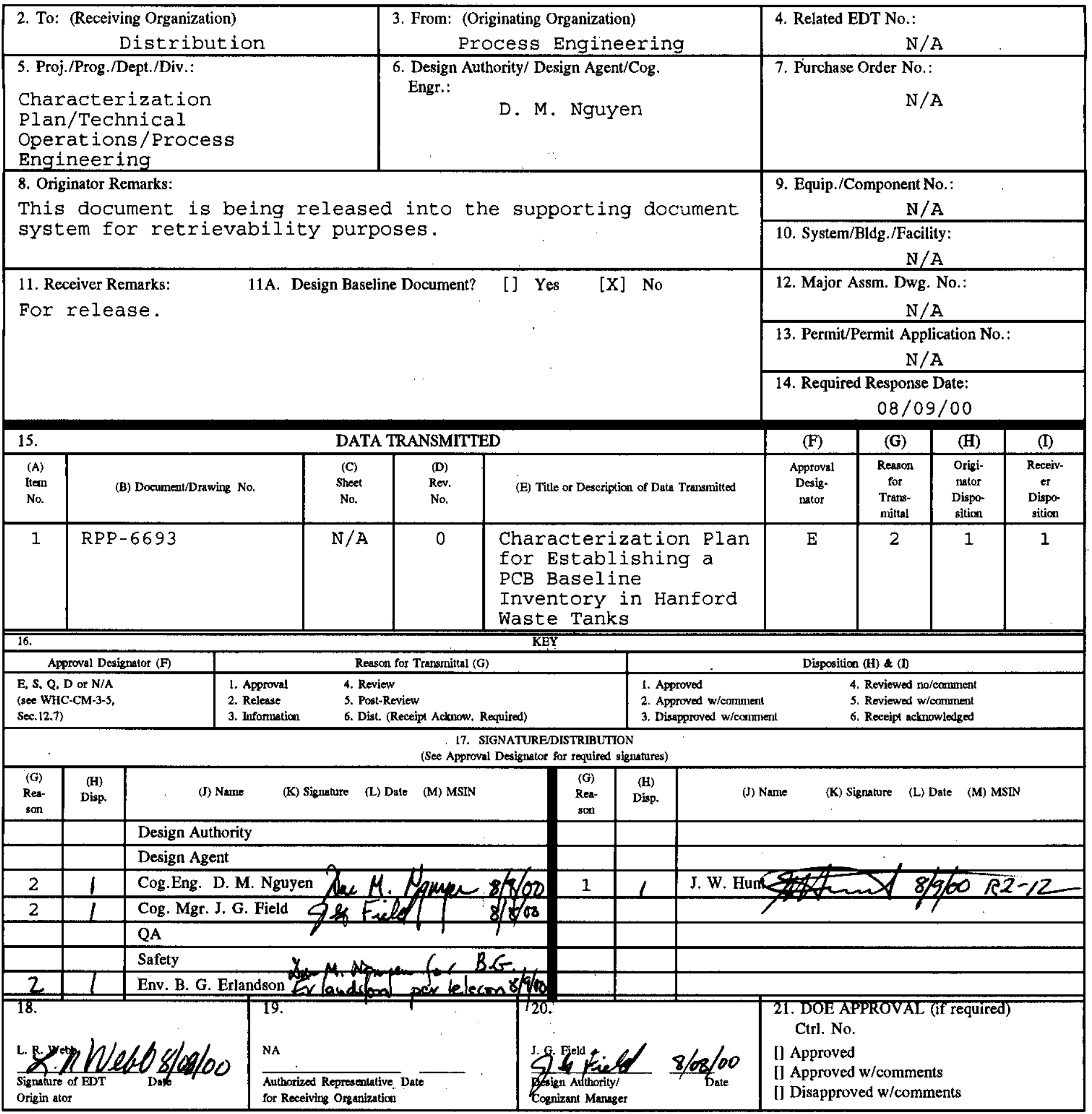

BD-7400-172-2 (05/96) GEF097 


\title{
Characterization Plan for Establishing a PCB Baseline Inventory in Hanford Waste Tanks
}

\author{
D. M. Nguyen \\ CH2M HILL Hanford Group, Inc., Richland, WA 99352 \\ U.S. Department of Energy Contract DE-AC06-96RL13200 \\ EDT/ECN : $\quad E D T-628395$ \\ UC: $\quad 2070$ \\ Org Code: $74 \mathrm{~B} 20$ \\ B\&R Code: EW 3120074 \\ CACN/COA: $112975 / \mathrm{CA} 10$ \\ Total Pages: $\mathbf{2} 4$ \\ Key Words: Characterization Plan, PCB Baseline Inventory, Hanford Waste \\ Tanks
}

Abstract :

$\mathrm{N} / \mathrm{A}$

TRADEMARK DISCLAIMER. Reference herein to any specific commercial product, process, or service by trade name, trademark, manufacturer, or otherwise, does not necessarily constitute or imply its endorsement, recommendation, or favoring by the United States Government or any agency thereof or its contractors or subcontractors.

Printed in the United States of America. To obtain copies of this document, contact: Document Control Services, P.O. Box 950, Mailstop H6-08, Richland WA 99352, Phone (509) 372-2420; Fax (509) 376-4989.
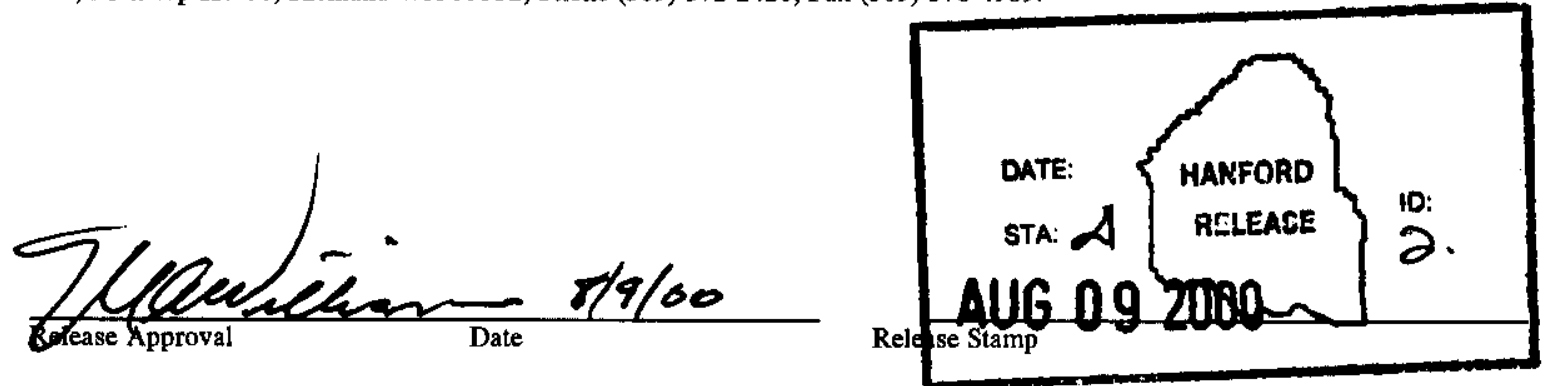

\section{Approved for Public Release}


RPP-6693

Revision 0

\title{
CHARACTERIZATION PLAN FOR ESTABLISHING A PCB BASELINE INVENTORY IN HANFORD WASTE TANKS
}

\author{
D. M. Nguyen \\ CH2M HILL Hanford Group, Inc.
}

Date Published

August 2000

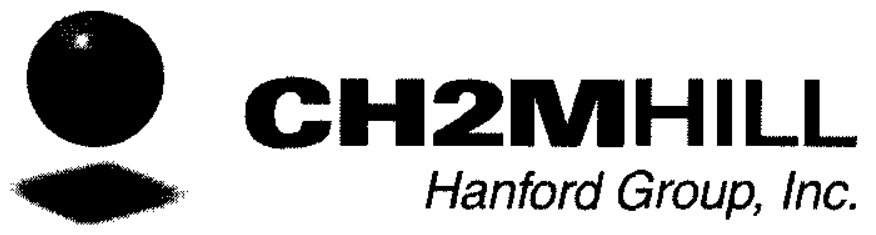

Prepared for the U.S. Department of Energy

Office of River Protection

Approved for public release; distribution unlimited 
RPP-6693 Rev. 0

\section{TABLE OF CONTENTS}

1.0 INTRODUCTION

1.1 PURPOSE

1.2 SCOPE

2.0 CHARACTERIZATION STRATEGY

2.1 PRIORITIZATION OF TANKS FOR PCB ANALYSIS ……................................... 8

2.2 SELECTION OF SAMPLES FOR ANALYSIS IN FISCAL YEAR 2001 .................... 10

2.3 BASIC ASSUMPTIONS ASSOCIATED WITH THE STRATEGY ……...................... 12

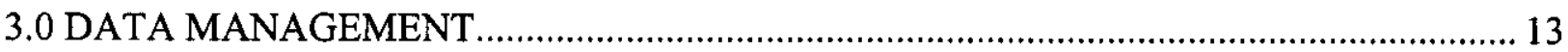

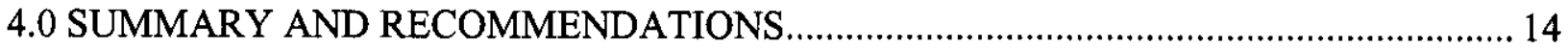

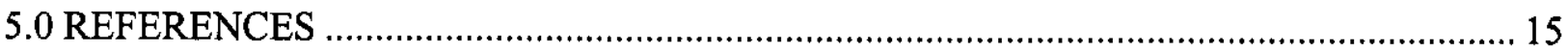

\section{APPENDICES}

APPENDIX A. PRIORITIZATION OF WASTE TANKS FOR PCB ANALYSIS 
RPP-6693 Rev. 0

\section{LIST OF FIGURES}

Figure 2-1. Possible PCB Transfer Routes into the DSTs. 6

\section{LIST OF TABLES}

Table 2-1. Phase I Treatment Waste Tanks 3

Table 2-2. Double-Shell Tanks Receiving Waste from Non-Double-Shell Tank Facilities 4

Table 2-3. Single-Shell Tanks Scheduled for Saltwell Pumping (Starting After October 2000). 5

Table 2-4. Phase II Single-Shell Tank Retrieval Sequence 7

Table 2-5. Tank Waste Planned for PCB Analysis In Fiscal Year 2001 9

Table 2-6. Archive Samples To Be Analyzed for PCBs In Fiscal Year 2001 11 


\section{RPP-6693 Rev. 0}

\section{LIST OF TERMS}

ATSDR

DCRT

DOE

DOE-ORP

DQO

DST

EPA

FY

g

HLW

LAW

$\mathrm{mL}$

PCB

RPP

SST

TSCA

WESF

WTF
Agency for Toxic Substances and Disease Registry

double-contained receiver tank

the U.S. Department of Energy

U.S. Department of Energy, Office of River Protection

data quality objective

double-shell tank

U.S. Environmental Protection Agency

fiscal year

grams

high-level waste

low-activity waste

milliliter

polychlorinated biphenyl

River Protection Project

single-shell tank

Toxic Substance Control Act

Waste Encapsulation and Storage Facility

Waste Treatment Facility 
RPP-6693 Rev. 0

\section{CHARACTERIZATION PLAN FOR ESTABLISHING A PCB INVENTORY IN HANFORD WASTE TANKS}

\subsection{INTRODUCTION}

In May 2000, the U.S. Department of Energy, Office of River Protection (DOE-ORP) and the U.S. Environmental Protection Agency (EPA) conducted meetings to discuss management of polychlorinated biphenyls (PCBs) in the Hanford tank waste. It was decided that the radioactive waste currently stored in the double-shell tanks (DSTs) will be managed to comply with the Toxic Substance Control Act (TSCA) (40 CFR 761). As a result, DOE-ORP directed the River Protection Project (RPP) tank farm contractor to prepare plans for managing the PCB inventory in the DSTs. One component of the PCB management plans is this characterization plan.

\subsection{PURPOSE}

At this time, available PCB data for Hanford tank waste is limited to thirteen DSTs and one single-shell tank (SST). Only concentration data for some individual Aroclors (i.e., commercial PCB mixtures) are available for these tanks. Total PCB data is needed to establish a baseline inventory of PCBs in the DSTs. Appropriate transfer controls for the tanks will be developed based on the baseline inventory. The controls will be used to ensure PCB levels in the DSTs will not exceed anticipated waste feed acceptance criteria of the Waste Treatment Facility (WTF).

Approximately ninety percent of the waste to be received at the DSTs in the future will come from the SSTs (Strode and Boyles 1999). Single-shell tank waste will be retrieved into the DSTs prior to treatment for disposal. Liquids from the SSTs currently are being transferred to the DSTs as part of the interim stabilization effort. In addition, waste sample materials taken from the SSTs have been and will continue to be sent to the DSTs after analysis by the site laboratories. Thus, to properly manage the PCB inventory in the DSTs, baseline characterization data of SST waste is also needed.

\subsection{SCOPE}

This PCB characterization plan describes an overall approach for establishing the baseline inventories for the waste tanks. All DSTs and SSTs are prioritized for PCB analysis according to data needs. Analyses to be performed in fiscal year (FY) 2001 for the highest-priority tanks are identified. Samples to be analyzed for PCBs in subsequent years will be specified in annual updates of this plan. 
This characterization plan only provides the strategy for prioritizing and selecting tanks and samples for PCB analysis. Specific requirements for PCB data quality will be provided in a data quality objective (DQO) document.

\subsection{CHARACTERIZATION STRATEGY}

A cost effective and timely method for obtaining PCB data is to use existing (i.e., archive) tank waste samples, when available, in combination with new samples that will be collected to support other program needs. This approach is consistent with initial guidance from the EPA and the U.S. Department of Energy (DOE). The 222-S Laboratory currently stores approximately 4,000 individual archive samples representing 15 DSTs and 88 SSTs. The number of samples and amount of waste material vary significantly from tank-to-tank. A strategy to select an appropriate subset of archive samples for PCB analysis is described in this section.

The main objective of the characterization strategy is to obtain sufficient PCB data to establish a baseline inventory that can be used with confidence for inventory control. The strategy also provides PCB data to support programmatic needs such as waste treatment, retrieval, and interim stabilization. The baseline inventory will be fully established when sufficient data are available to satisfy the following needs:

- Data to determine the PCB inventory in waste tanks currently planned for Phase I vitrification. The inventory estimates will be used to maintain PCB concentrations below waste feed acceptance limits of the vitrification plant. In the unlikely event that PCB levels in a tank exceed the WTF acceptance limits, data will be available in a timely manner to determine an acceptable pathway for processing the waste.

The tank wastes to be treated in the Phase I vitrification are identified in the Tank Farm Contractor Operations and Utilization Plan (Kirkbride 2000). A summary of these tanks is shown in Table 2-1. 
Table 2-1. Phase I Treatment Waste Tanks

\begin{tabular}{|c|c|c|c|}
\hline \multicolumn{2}{|c|}{ Low-Activity Waste } & \multicolumn{2}{|c|}{ High-Level Waste } \\
\hline Tank & Treatment Batch & Tank & Treatment Batch \\
\hline 241-AP-101 & $1^{2}$ & $241-\mathrm{AZ}-101$ & $1^{2}$ \\
\hline 241-AZ-101 & $2^{2}$ & 241-AZ-102 & $2^{2}$ \\
\hline 241-AZ-102 & $2^{2}$ & $\begin{array}{c}241-\mathrm{AY}-102 \\
\text { (From 241-C-106) }\end{array}$ & $3^{2}$ \\
\hline $241-\mathrm{AN}-102$ & $3,4^{\mathrm{a}}$ & $\begin{array}{l}241-\mathrm{AY}-101 \\
241-\mathrm{C}-104\end{array}$ & $4^{2}$ \\
\hline 241-AN-104 & $5,6^{2}$ & 241-SY-102 & $5^{a}$ \\
\hline $241-\mathrm{AN}-107$ & $7^{2}$ & $\begin{array}{c}241-\mathrm{C}-107 \\
241-\mathrm{AW}-103\end{array}$ & $6^{5}$ \\
\hline 241-AN-105 & $8,9^{2}$ & $\begin{array}{l}241-\mathrm{AW}-104 \\
241-\mathrm{AW}-103\end{array}$ & $7^{\circ}$ \\
\hline $\begin{array}{l}241-\mathrm{SY}-101 / \\
241-\mathrm{AP}-104\end{array}$ & $10,11^{2}$ & -- & -- \\
\hline $241-\mathrm{AN}-103$ & $12,13^{\mathrm{a}}$ & -- & -- \\
\hline 241-AW-101 & $14,15^{2}$ & -- & -- \\
\hline $241-A W-104$ & $16^{6}$ & - & -- \\
\hline 241-SY-103 & $17^{\circ}$ & $\cdots$ & -- \\
\hline 241-AP-106 & $18,19^{\circ}$ & -- & -- \\
\hline $\begin{array}{c}241-\mathrm{S}-102 \\
(241-\mathrm{S}-103)^{\mathrm{c}} \\
(241-\mathrm{S}-105)^{\mathrm{c}} \\
\end{array}$ & $20^{\circ}$ & -- & - \\
\hline $\begin{array}{c}241-\mathrm{S}-105 \\
(241-\mathrm{S}-106)^{\mathrm{c}} \\
(241-\mathrm{S}-108)^{\mathrm{c}} \\
\end{array}$ & $21^{\circ}$ & -- & -- \\
\hline 241-ĀP-105 & $22,23^{\circ}$ & -- & -- \\
\hline 241-AP-108 & $24^{\circ}$ & - & -- \\
\hline
\end{tabular}

Notes:

a Tank waste is part of the minimum order for treatment feed.

${ }^{b}$ Tank waste is part of the extended order for feed.

'Additional feed source as needed. 
- Data to estimate the PCB inventory in DSTs that are currently or will be used to receive waste from non-DST facilities. This data, in addition to the PCB data for the incoming waste, will be needed to control the PCB inventory in the DSTs. The Data Quality Objectives for Tank Farms Waste Compatibility Program (Mulkey et al. 1999) will be revised to provide PCB data requirements for incoming non-DST waste. The list of DST receiver tanks is maintained by the Waste Inventory and Modeling group. A summary of these tanks and of the sources of incoming wastes is shown in Table 2-2.

Table 2-2. Double-Shell Tanks Receiving Waste from Non-Double-Shell Tank Facilities

\begin{tabular}{|l|l|}
\hline \multicolumn{1}{|c|}{ DST Receiver } & Potential Non-DST Waste Sources \\
\hline $241-\mathrm{SY}-102$ & $\begin{array}{l}\text { Saltwell Pumping, Plutonium Finishing Plant (PFP), } \\
\text { 222-S Laboratory }\end{array}$ \\
\hline $241-\mathrm{AW}-106$ & 242-A Evaporator \\
\hline $241-\mathrm{AW}-105$ & $\begin{array}{l}\text { 100 Area, Inactive Miscellaneous Underground Storage } \\
\text { Tanks (IMUSTs) }\end{array}$ \\
\hline $241-\mathrm{AP}-108$ & $\begin{array}{l}\text { Saltwell Pumping, 300 Area, Plutonium-Uranium } \\
\text { Extraction Plant (PUREX), B Plant, Waste Encapsulation } \\
\text { and Storage Facility (WESF) }\end{array}$ \\
\hline $241-\mathrm{AN}-101$ & Saltwell Pumping \\
\hline
\end{tabular}

Some of the non-DST wastes will be transferred to the DSTs through doublecontained receiver tanks (DCRT) and catch tanks. These miscellaneous tanks generally contain a residual amount of waste. If $\mathrm{PCBs}$ are present in the miscellaneous tanks, the PCBs could be transferred into the DSTs along with the nonDST waste. However, the compatibility DQO program requires that samples be taken from all sources of incoming waste, including those from DCRTs and catch tanks. PCB analysis will be performed on these samples per the DQO and the data will be used for controlling the PCB inventory of the DST receiver tank.

- Data to estimate the amount of PCBs, if any, that will be transferred into the DSTs as a result of the SST interim stabilization program. Under this project, liquid is being removed from the SSTs via saltwell pumping and transferred to the DSTs. The SST interim stabilization is an on-going effort. A saltwell-pumping schedule can be found in the Single-Shell Tank Interim Stabilization Project Plan (Vladimiroff 2000). A list of tanks to be interim-stabilized is provided in Table 2-3. 
Table 2-3. Single-Shell Tanks Scheduled for Saltwell Pumping (Starting After October 2000)

\begin{tabular}{|c|c|}
\hline Tank & Start Date \\
\hline $241-\mathrm{SX}-103$ & FY 2001 \\
\hline $241-\mathrm{SX}-101$ & FY 2001 \\
\hline $241-\mathrm{U}-106$ & FY 2001 \\
\hline $241-\mathrm{BY}-106$ & FY 2001 \\
\hline $241-\mathrm{BY}-105$ & FY 2001 \\
\hline $241-\mathrm{U}-108$ & FY 2002 \\
\hline $241-\mathrm{U}-107$ & FY 2002 \\
\hline $241-\mathrm{S}-111$ & FY 2002 \\
\hline $241-\mathrm{SX}-102$ & FY 2002 \\
\hline $241-\mathrm{U}-111$ & FY 2003 \\
\hline $241-\mathrm{S}-109$ & FY 2003 \\
\hline $241-\mathrm{S}-112$ & FY 2003 \\
\hline $241-\mathrm{S}-101$ & FY 2003 \\
\hline $241-\mathrm{S}-107$ & FY 2003 \\
\hline $241-\mathrm{C}-103$ & FY 2003 \\
\hline
\end{tabular}

The current pumping of saltwell liquid without PCB data poses a risk to the PCB inventory in the DSTs. However, this risk is expected to be minor because a significant amount of SST liquid waste has already been transferred into the DSTs over the years and the incremental amount of saltwell liquid being added is comparatively small. Also, the risk due to pumping SST liquid is small because PCBs are slightly soluble in water and their molecules have a tendency to attach themselves to sediment (i.e., solids) particles (ATSDR 2000). However, it is desirable to further minimize this risk by obtaining PCB data for as many SSTs scheduled for saltwell pumping as allowed by other PCB data needs.

- Data to estimate the PCB inventory in DSTs that received waste from generating facilities that may have used PCBs in their operations. A screening of waste generating and transfer records indicates that 340 Facility, 222-S Laboratory, B-Plant, WESF, and T-Plant may have used PCBs in their operations. Twelve DSTs may have received waste from these facilities: 241-C-106, 241-AY-102, 241-AP-106, 241-AP-108, 241-AP-104, 241-SY-102, 241-AW-102, 241-AW-106, 241-AP-107, 241-AP-101, 241-AP-105, and 241-AP-103. If present in the DSTs, PCBs would most likely be detected in samples taken from these tanks. Data from these tanks would provide an indication of the bounding PCB level in DST waste. A chart showing the potential routes for PCB transfer from the facilities to the DSTs is provided in Figure 2-1. 
RPP-6693 Rev. 0

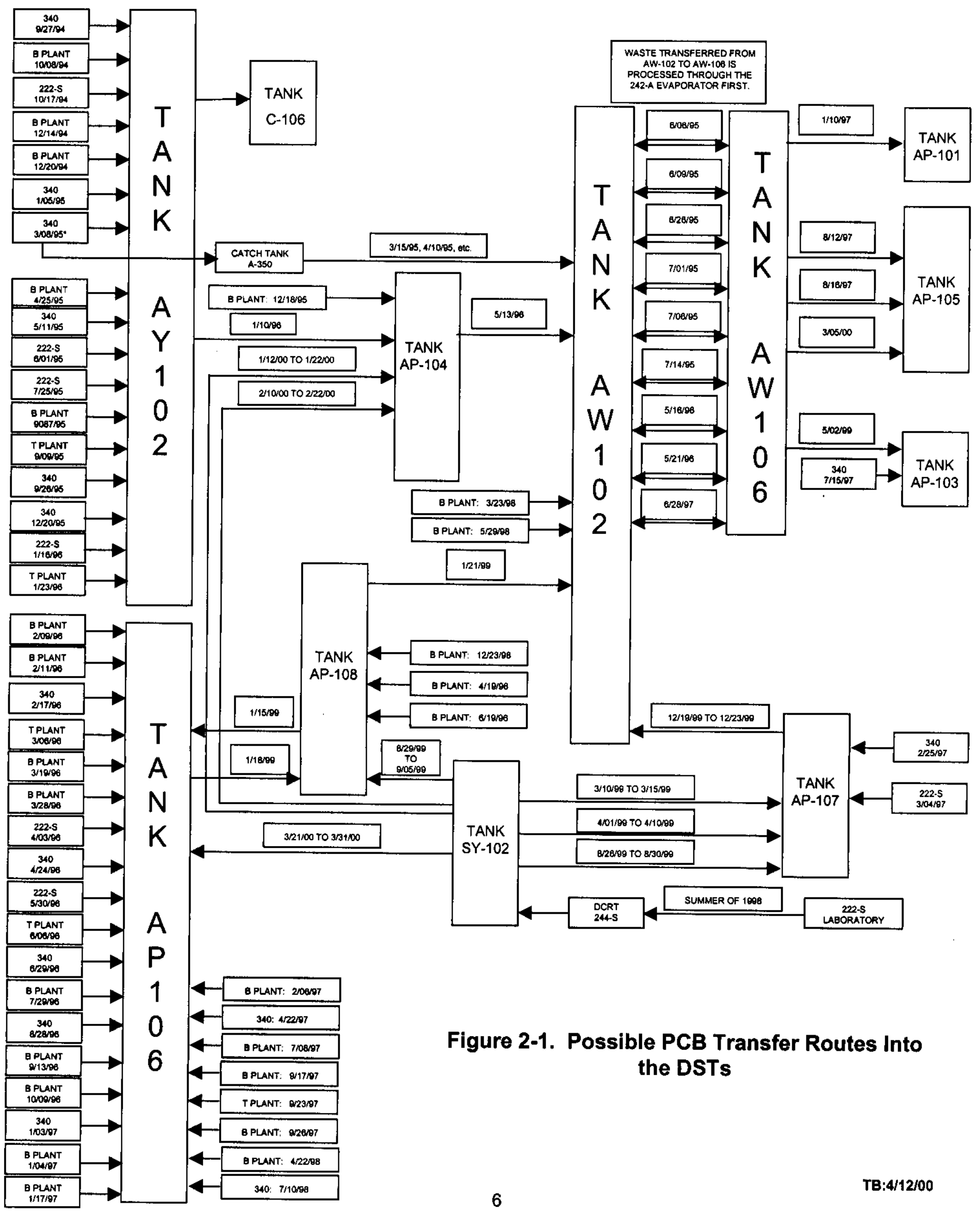


- Data for the remaining DSTs: 241-AN-101, 241-AN-106, and 241-AP-102. PCB data for these tanks will complete the inventory for all DSTs.

- Data to estimate the inventory in SSTs to be retrieved in support of the waste feed delivery for Phase II treatment. Technical basis for the data needs is the same as that for the Phase I tanks. However, Phase II waste PCB data will not be needed as early. The SST waste retrieval sequence is being maintained by the SST Retrieval Project. Table 2-4 identifies fifteen tanks that have been scheduled for retrieval and the expected retrieval dates.

Table 2-4. Phase II Single-Shell Tank Retrieval Sequence

\begin{tabular}{|c|c|}
\hline Tank & Planned Start Date \\
\hline $241-\mathrm{S}-106$ & 2011 \\
\hline $241-\mathrm{S}-108$ & 2012 \\
\hline $241-\mathrm{S}-109$ & 2012 \\
\hline $241-\mathrm{S}-112$ & 2013 \\
\hline $241-\mathrm{S}-107$ & 2014 \\
\hline $241-\mathrm{S}-110$ & 2014 \\
\hline $241-\mathrm{A}-101$ & 2015 \\
\hline $241-\mathrm{AX}-103$ & 2015 \\
\hline $241-\mathrm{AX}-101$ & 2015 \\
\hline $241-\mathrm{TX}-112$ & 2017 \\
\hline $241-\mathrm{BY}-102$ & 2017 \\
\hline $241-\mathrm{BY}-111$ & 2017 \\
\hline $241-\mathrm{BY}-112$ & 2017 \\
\hline $241-\mathrm{C}-102$ & 2018 \\
\hline $241-\mathrm{C}-103$ & 2018 \\
\hline
\end{tabular}

The remaining SSTs are currently planned to be retrieved by a "privatization" contractor. A tank-specific retrieval schedule has not been developed but retrieval is not expected to start until after 2010. Prior to waste retrieval, these tanks will be sampled and analyzed for process development (e.g., retrievability and treatability) and to satisfy the compatibility DQO (Mulkey et al. 1999). PCB data will be obtained for these tanks at that time. 
To achieve the stated objectives, the characterization strategy consists of the following steps:

1. Prioritize waste tanks according to program needs for PCB data.

2. Identify high-priority tanks from which new samples will be taken to support other programs. PCB analyses will be "opportunistically" performed on these tank wastes. The tanks are selected only if sufficient sample material is likely to remain after completion of the other analyses.

3. Evaluate and identify archive samples for PCB analysis of waste in the other high-priority tanks.

If results from this baseline characterization effort indicate elevated levels of PCBs in a tank, additional sampling and analysis may be performed as necessary. The need for additional PCB data will be addressed in the PCB analysis DQO.

\subsection{PRIORITIZATION OF TANKS FOR PCB ANALYSIS}

Prioritization of tanks for PCB characterization is achieved by assigning numerical values to each category of tanks according to the magnitude and urgency of the data needs. A sum of the assigned values is calculated for each tank. Overall priority is determined by the total values. The assigned values are discussed below.

- The potential impact of elevated levels of PCBs in DSTs and SSTs planned for Phase I vitrification is expected to be the largest. If required, treatment of PCBs would add a significant amount to the cost of the vitrification facility. It is desirable to obtain data for the first tanks to be treated as early as possible. Thus, the tanks scheduled to be treated early have slightly higher ranking values than the others.

High-level waste (HLW) and low-activity waste (LAW) to be treated are currently divided into "minimum order tanks" and "extended order tanks." The "minimum order tanks" will be treated first. The first HLW and LAW tanks in the minimum order are assigned a ranking value of 100 . Each subsequent tank is assigned a value one less than the preceding tank. For example, the first tank is assigned a value of 100 , the next tank 99, and the one after that 98, etc. The first tank in the extended order is assigned a value of 70; each subsequent tank is assigned a value of one less than the preceding tank.

- Estimates of PCBs in the DST receivers are important for inventory control. These tanks are assigned a value of 90 . 
- DSTs that received waste from generating facilities which may have used PCBs in their operations are the most likely to contain PCBs at detectable levels. Data from these tanks may provide an indication of the bounding concentration in the other DSTs. These tanks are assigned a value of 80 .

- A major source of waste to be received by the DSTs is saltwell liquid. Interstitial liquid from a number of SSTs is being pumped to the DSTs at this time. After the start of FY 2001 when PCB analysis will begin, fifteen SSTs remains to be interim stabilized. The first tank scheduled for pumping is assigned a value of 75 , each subsequent tank is assigned a value of one less than the preceding tank.

- Data from the remaining DSTs would complete the inventory for the DSTs. These tanks are assigned a value of 50 .

- The needs for data from the Phase II SSTs to be retrieved by the RPP tank farm contractor are the same as those for the Phase I tanks. However, the data would be needed much later. The first Phase II tank is assigned a value of 40 , each subsequent tank is assigned a value of one less than the preceding tank.

Overall ranking of the 177 waste tanks for PCB analysis is shown in Appendix A. Based on the current funding guidelines, waste from twenty-four tanks will be analyzed for PCBs annually. Table 2-5 shows the highest-priority tanks that are planned for PCB analysis in FY 2001.

Table 2-5. Tank Waste Planned for PCB Analysis In Fiscal Year 2001 (2 Sheets)

\begin{tabular}{|c|c|}
\hline Tank & Priority \\
\hline $241-\mathrm{SY}-102$ & 1 \\
\hline $241-\mathrm{AP}-108$ & 2 \\
\hline $241-\mathrm{AP}-101$ & 3 \\
\hline $241-\mathrm{AY}-102$ & 4 \\
\hline $241-\mathrm{AP}-104$ & 5 \\
\hline $241-\mathrm{AW}-106$ & 6 \\
\hline $241-\mathrm{C}-107$ & 7 \\
\hline $241-\mathrm{AP}-106$ & 8 \\
\hline $241-\mathrm{AP}-105$ & 9 \\
\hline $241-\mathrm{S}-106$ & 10 \\
\hline $241-\mathrm{S}-108$ & 11 \\
\hline $241-\mathrm{S}-109$ & 12 \\
\hline $241-\mathrm{S}-112$ & 13 \\
\hline $241-\mathrm{AZ}-101$ & 14 \\
\hline $241-\mathrm{AZ}-102$ & 15 \\
\hline $241-\mathrm{S}-107$ & 16 \\
\hline $241-\mathrm{AN}-102$ & 17 \\
\hline $241-\mathrm{C}-104$ & 18 \\
\hline
\end{tabular}


RPP-6693 Rev. 0

Table 2-5. Tank Waste Planned for PCB Analysis In Fiscal Year 2001 (2 Sheets)

\begin{tabular}{|c|c|}
\hline Tank & Priority \\
\hline $241-\mathrm{AN}-104$ & 19 \\
\hline $241-\mathrm{A} \mathrm{Y}-101$ & 20 \\
\hline $241-\mathrm{AN}-107$ & 21 \\
\hline $241-\mathrm{AN}-105$ & 22 \\
\hline $241-\mathrm{SY}-101$ & 23 \\
\hline $241-\mathrm{AN}-103$ & 24 \\
\hline $241-\mathrm{C}-103^{(2)}$ & 25 \\
\hline
\end{tabular}

${ }^{(*)}$ Neither archive nor new samples will be available for tank 241-S-108 in FY 2001. Tank 241-C-103 is added as a replacement.

\subsection{SELECTION OF SAMPLES FOR ANALYSIS IN FISCAL YEAR 2001}

The "Baseline Sampling Schedule, Change 00-01" (Stanton 2000) is used to identify five tanks from which new samples will be analyzed for PCBs in FY 2001. The tanks are:

$$
\begin{aligned}
& 241-\mathrm{SY}-102, \\
& 241-\mathrm{AP}-104, \\
& 241-\mathrm{C}-107, \\
& 241-\mathrm{AN}-107 \text {, and } \\
& 241-\mathrm{S}-112 .
\end{aligned}
$$

These tanks are planned for sampling to support other programs. If sampling of a tank is no longer needed by the programs, another tank will be selected from the prioritized list (shown in Appendix A) for PCB analysis. Sample number and type for these tanks will be specified in tank-specific sampling and analysis plans.

The 222-S Laboratory archive sample database is examined to determine the appropriate samples for the other nineteen tanks. In order to estimate the statistical uncertainty associated with the data, two samples from each phase (liquid or solids) is needed. However, when there is only one archive sample for a phase in a high-priority tank, PCB analysis will be performed on that sample. Data uncertainty for the phase will be estimated when the tank is sampled to support other programs.

To optimize representativeness of final data, available archive samples are selected based on the following order of preference:

1. Core composite samples from different risers,

2. Core composite samples from the same riser,

3. Segment samples from cores taken from different risers, 
4. Segment samples from the same core or riser,

5. Grab samples taken from different risers, and

6. Grab samples taken from the same riser.

In addition, most recent samples are used if everything else is equal. Archive samples are not used if the sample size is insufficient for analysis (i.e., less than approximately $2 \mathrm{~g}$ for solids or $100 \mathrm{~mL}$ for liquid). Archive samples may not be used if characteristics of the waste in the tank have been altered due to addition of other waste since the samples were taken.

Table 2-6 shows the archive samples that are planned for PCB analysis in FY 2001. Quality assurance/quality control requirements for the analyses will be addressed in the PCB analysis DQO. This characterization plan will be revised annually to provide an update of the table for the following year.

Table 2-6. Archive Samples To Be Analyzed for PCBs In Fiscal Year 2001 (2 Sheets)

\begin{tabular}{|c|c|c|c|c|}
\hline Tank & 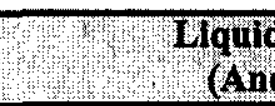 & mples & $\begin{array}{l}\text { Soldas } \\
\text { (And }\end{array}$ & mples \\
\hline 241-AP-108 & $\begin{array}{c}\text { 8AP-99-2 } \\
\text { (grab) }\end{array}$ & $\begin{array}{c}8 \mathrm{AP}-99-4 \\
\text { (grab) }\end{array}$ & Not Available & Not Available \\
\hline 241-AP-101 & $\begin{array}{l}1 \mathrm{AP}-95-1 \text { and } 2 \\
\text { (combined grab) }\end{array}$ & $\begin{array}{l}\text { 1AP-95-5 and } 6 \\
\text { (combined grab) }\end{array}$ & Not Available & Not Available \\
\hline $241-A Y-102$ & $\begin{array}{l}\text { Core } 270, \\
\text { Segment } 1 \\
\end{array}$ & $\begin{array}{r}\text { Core } 273, \\
\text { Segment } 7 \\
\end{array}$ & Core 270, Segment 10 & Not Available \\
\hline $241-A W-106$ & $\begin{array}{c}\text { 6AW-97-4 } \\
\text { (grab) }\end{array}$ & $\begin{array}{c}\text { 6AW-97-5 } \\
\text { (grab) }\end{array}$ & $\begin{array}{c}\text { 6AW-97-6 } \\
\text { (grab) }\end{array}$ & Not Available \\
\hline $241-\mathrm{AP}-106$ & $\begin{array}{l}\text { 6AP-96-2 and } 3 \\
\text { (combined grab) }\end{array}$ & $\begin{array}{l}\text { 6AP-97-1,2, and } \\
3 \\
\text { (combined grab) }\end{array}$ & Not Available & Not Available \\
\hline 241-AP-105 & $\begin{array}{l}\text { Core } 208, \\
\text { Segment } 1 \\
\end{array}$ & $\begin{array}{l}\text { Core 209, } \\
\text { Segment } 1 \\
\end{array}$ & Core 208 , Segment 1 & Core 209 , Segment 3 \\
\hline $241-S-106$ & $\begin{array}{l}\text { Core 183, } \\
\text { Segment } 1\end{array}$ & $\begin{array}{l}\text { Core 184, } \\
\text { Segment 6R }\end{array}$ & Core 183 , Segment 8 & Core 184, Segment 2 \\
\hline $241-S-108$ & $\begin{array}{c}\text { No archive nor } \\
\text { new samples } \\
\text { available }^{(*)}\end{array}$ & $\begin{array}{l}\text { No archive nor } \\
\text { new samples } \\
\text { available } \\
\end{array}$ & $\begin{array}{l}\text { No archive nor new } \\
\text { samples available }\end{array}$ & $\begin{array}{l}\text { No archive nor new } \\
\text { samples available }\end{array}$ \\
\hline $241-S-109$ & $\begin{array}{c}\text { 9S-99-1 } \\
\text { (grab) }\end{array}$ & $\begin{array}{l}\text { 9S-99-3 } \\
\text { (grab) }\end{array}$ & Core 158 , Segment 3 & Core 160, Segment 1 \\
\hline $241-A Z-101$ & $\begin{array}{c}\text { 1AZ-00-66 } \\
\text { (grab) }\end{array}$ & $\begin{array}{c}\text { 1AZ-00-59 } \\
\text { (grab) }\end{array}$ & $\begin{array}{c}\text { 1AZ-00-67 } \\
\text { (grab) }\end{array}$ & $\begin{array}{c}1 \mathrm{AZ}-00-59 \\
\text { (grab) }\end{array}$ \\
\hline 241-AZ-102 & $\begin{array}{l}\text { Core } 261 \\
\text { composite }\end{array}$ & $\begin{array}{l}\text { Core } 262 \\
\text { composite }\end{array}$ & Not Available & Not Available \\
\hline
\end{tabular}


Table 2-6. Archive Samples To Be Analyzed for PCBs In Fiscal Year 2001 (2 Sheets)

\begin{tabular}{|c|c|c|c|c|}
\hline Tank & \multicolumn{2}{|c|}{$\begin{array}{l}\text { Equid Samples } \\
\text { (And Type) }\end{array}$} & \multicolumn{2}{|c|}{$\begin{array}{l}\text { Sollds Samples } \\
\text { (And Type) }\end{array}$} \\
\hline $241-5-107$ & $\begin{array}{l}\text { Core 111, } \\
\text { Segment } 1\end{array}$ & $\begin{array}{c}\text { Core } 105 \\
\text { Segments } 1 \text { and } 2\end{array}$ & Core 111 composite & Core 105 composite \\
\hline $241-\mathrm{A} N-102$ & $\begin{array}{c}\text { 2AN-98-2 } \\
\text { (grab) }\end{array}$ & $\begin{array}{l}\text { S95T0041 } \\
\text { (grab) }\end{array}$ & Not Available & Not Available \\
\hline $241-C-104$ & $\begin{array}{l}\text { No liquid remains } \\
\text { in tank }\end{array}$ & $\begin{array}{c}\text { No liquid remains } \\
\text { in tank }\end{array}$ & Core 162 composite & Core 165 composite \\
\hline 241-A $\bar{N}-104$ & $\begin{array}{c}\text { Core } 164 \\
\text { composite }\end{array}$ & $\begin{array}{l}\text { Core 163, } \\
\text { Segment } 21\end{array}$ & Core 164 composite & Core 163 composite \\
\hline $241-\mathrm{A} \overline{Y-101}$ & $\begin{array}{l}\text { Core 275, } \\
\text { Segment } 1\end{array}$ & $\begin{array}{c}\text { Core 276, } \\
\text { Segment 2R }\end{array}$ & $241-\mathrm{AN}-104$ & Core 276, Segment 3R \\
\hline $241-\mathrm{A} N-105$ & $\begin{array}{l}\text { Core } 152 \\
\text { composite }\end{array}$ & $\begin{array}{c}\text { Core } 153 \text { Segment } \\
21\end{array}$ & Core 152 composite & Core 153 composite \\
\hline $241-\mathrm{S} \bar{Y}-101$ & $\begin{array}{c}\text { 1SY-00-1, } \\
\text { 1SY-00-2 } \\
\text { (combined grab) }\end{array}$ & $\begin{array}{c}\text { 1SY-00-4, } \\
1 \mathrm{SY}-00-5 \\
\text { (combined grab) }\end{array}$ & $\begin{array}{c}1 \mathrm{SY}-00-1 \\
\text { (grab) }\end{array}$ & $\begin{array}{l}\text { 1SY-00-5 } \\
\text { (grab) }\end{array}$ \\
\hline $241-\mathrm{AN}-103$ & $\begin{array}{l}\text { Core } 166 \\
\text { composite }\end{array}$ & $\begin{array}{l}\text { Core } 167 \\
\text { composite }\end{array}$ & Core 166 composite & Core 167, Segment 11 \\
\hline $241-C-103$ & $\begin{array}{c}\text { Core } 63 \text {, Segment } \\
1\end{array}$ & $\begin{array}{c}\text { Core 66, Segment } \\
2\end{array}$ & Core 63 , Segment 3 & Core 66 , Segment 4 \\
\hline
\end{tabular}

${ }^{(*)}$ No archive nor new samples available for tank 241-S-108 in FY 2001. Tank 241-C-103 is added as a replacement.

\subsection{BASIC ASSUMPTIONS ASSOCIATED WITH THE STRATEGY}

The baseline characterization strategy and schedule are based on a number of assumptions. The assumptions and their implications are discussed below.

- Archive samples were taken to support various Tank Farm activities such as operations, safety issue resolution, process development, etc. It is unlikely that these samples were taken in accordance with EPA protocols for semi-volatile (including PCB) samples. The EPA's SW-846 manual, Test Methods for Evaluating Solid Waste, Physical/Chemical Methods (EPA 1992) specifies 8-ounce wide-mouth glass bottles with Teflon ${ }^{\mathrm{TM}}$ liner be used for collecting these samples. SW- 846 also specifies extraction of the samples within 14 days of sampling, and analysis within 40 days following extraction. Most of the existing samples have been stored for years and, therefore, would not meet the extraction requirement. However, the intent of these requirements is to minimize losses of the waste constituents of concern before analysis. Because PCBs are stable compounds, losses while in storage are expected to be small. Data obtained from archive samples are valid for inventory control purposes. 
- Waste analysis process consists of many steps. In general, laboratory activities include sample preparation, analysis, data quality review, and data documentation. After the laboratory data report is issued, RPP Process Engineering evaluates the data against existing knowledge of the waste, enters the data into a database, and documents the data evaluation in a characterization report. This process can take many months to complete. For planning purposes, the term "PCB analysis" is defined in this characterization plan as completion of laboratory analysis.

Preliminary data will be available at that time for use as an early indication of PCB level in a waste tank.

- The planned PCB analyses are based on the current budget guidelines. A significant change in the guidelines would require modifications to the proposed plan for PCB analysis.

\subsection{DATA MANAGEMENT}

Requirements for data handing and reporting will be specified in a guidance document to the analytical laboratory. The guidance document may be in the form of a letter of instruction or equivalent (e.g., a sampling and analysis plan). Collected data will be maintained in a PCB database as described in the Management Plan of Polychlorinated Biphenyl Inventory in the Double-Shell Tank System (Lechelt 2000). The PCB data will also be stored in the Tank Characterization Database (TCD) (CHG 2000) along with nonPCB waste characterization data. Data in the TCD is accessible to members of the public via the Internet at http://twins.pnl.gov:8001/TCD/main.html. Also, PCB data will be used to determine the Best Basis Inventory (BBI) estimates for individual tanks. 


\subsection{SUMMARY AND RECOMMENDATIONS}

As a result of recent negotiations with the EPA, DOE-ORP directed the RPP tank farm contractor to prepare plans for managing the $\mathrm{PCB}$ inventory in Hanford underground waste tanks. This characterization plan provides a strategy for obtaining sufficient PCB data to establish a baseline inventory that can be used with confidence for inventory control. A cost effective and timely approach for obtaining PCB data is to use archive samples, when available, in combination with new samples that will be collected to support other program needs. This approach is consistent with initial guidance from the EPA and DOE.

Because the need for PCB data by programs such as treatment, interim stabilization, and retrieval are different, the 177 waste tanks are prioritized according to the potential impacts on the programs and the urgency of the data needs. The priority for PCB analysis for the tanks is presented in Appendix A.

Based on the current budget guidelines, samples from twenty-four tanks are planned for PCB analysis annually. The highest-priority tanks have been identified for PCB analysis in FY 2001. Five tanks from which new samples will be analyzed for PCBs are identified in Section 2.2. Sampling of these tanks is planned to support other program needs. If data for any of these tanks is no longer required by the programs, the tank will be replaced by another from the prioritized list. Sample number and type for these tanks will be specified in tank-specific sampling and analysis plans. Archive samples are specified for the other nineteen tanks as shown in Table 2-6. Data quality requirements for all PCB analyses will be specified in a DQO document to be issued in October 2000 .

If analytical data indicates elevated levels of PCBs in a tank, additional sampling and analysis may be required. The need for additional data will be addressed by the PCB analysis DQO.

This characterization plan will be updated annually to select the tanks and samples for PCB analysis in the following year. Also, the prioritization in Appendix A should be reevaluated when a schedule for the Phase II "privatized" retrieval is more firmly established. 


\subsection{REFERENCES}

ATSDR, 2000, Polychlorinated Biphenyls (PCBs) Fact Sheet, Agency for Toxic Substances and Disease Registry, Atlanta, Georgia.

CHG, 2000, Tank Characterization Database at http://twins.pnl.gov:8001/TCD/main.html, CH2M HILL Hanford Group, Inc., Richland, Washington.

EPA, 1992, Test Methods for Evaluating Solid Waste, Physical/Chemical Methods, SW-846, Third Edition, U.S. Environmental Protection Agency, Washington, D. C.

Kirkbride, R. A., 2000, Tank Farm Contractor Operations and Utilization Plan, HNF-SD-WM-SP-012, Rev.2, Numatec Hanford Corporation, Richland, Washington.

Lechelt, J. A., 2000, Management Plan of Polychlorinated Biphenyl Inventory in the Double-Shell Tank System, RPP-6623, CH2M HILL Hanford Group, Inc., Richland, Washington.

Mulkey, C. H., M. Miller, and L. Jackson, 1999, Data Quality Objectives for Tank Farms Waste Compatibility Program, HNF-SD-WM-DQO-001, Rev. 3, Lockheed Martin Hanford Corporation, Richland, Washington.

Stanton, G. A., 2000, Baseline Sampling Schedule, Change 00-01, (Internal memorandum 79500-00-GAS-001, to Distribution, Dated January 10), CH2M HILL Hanford Group, Inc., Richland, Washington.

Strode, J. N., and V. C. Boyles, 1999, Operational Waste Volume Projection, HNF-SD-WM-ER-029, Rev. 25, Lockheed Martin Hanford Corporation, Richland, Washington.

Vladimiroff, D. T., 2000, Single-Shell Tank Interim Stabilization Project Plan, HNF-2358, Rev. 4, CH2M HILL Hanford Group, Inc., Richland, Washington.

40 CFR 761, 1998, "Polychlorinated Biphenyls (PCB) Manufacturing, Processing, Distribution in Commerce, and Use Prohibitions," Title 40, Code of Federal Regulations, Part 761, as amended, U.S. Environmental Protection Agency, Washington, D. C. 
RPP-6693 Rev. 0

APPENDIX A

PRIORITIZATION OF WASTE TANKS FOR PCB ANALYSIS 
RPP-6693 Rev. 0

Table A-1: Prioritization of Tanks for PCB Characterization

\begin{tabular}{|c|c|c|c|c|c|c|c|}
\hline Tank & Treatment & Saltwell & PCB Susp. & SST Retrleval & DST Recelver & Remaining DSTs & Total \\
\hline $5 Y-102$ & 95 & & 80 & & 90 & & 265 \\
\hline$A P-108$ & 64 & & 80 & & 90 & & 234 \\
\hline$A P-101$ & 100 & & 80 & & & & 180 \\
\hline$A Y-102$ & 98 & & 80 & & & & 178 \\
\hline AP-104 & 94. & & 80 & & & & 174 \\
\hline AW-106 & & & 80 & & 90 & & 170 \\
\hline C-107 & 70 & & 80 & & & & 150 \\
\hline AP-106 & 68 & & 80 & & & & 148 \\
\hline AP-105 & 65 & & 80 & & & & 145 \\
\hline S-106 & 66 & & & 40 & & & 106 \\
\hline S-108 & 66 & & & 39 & & & 105 \\
\hline s-109 & & 65 & & 38 & & & 103 \\
\hline S-112 & & 64 & & 37 & & & 101 \\
\hline$A Z-101$ & 100 & & & & & & 100 \\
\hline $\bar{A} Z-102$ & 99 & & & & & & 99 \\
\hline S-107 & & 62 & & 36 & & & 98 \\
\hline $\mathrm{AN}-102$ & 98 & & & & & & 98 \\
\hline C-104 & 97 & & & & & & 97 \\
\hline $\mathrm{AN}-104$ & 97 & & & & & & 97 \\
\hline AY-101 & 97 & & & & & & 97 \\
\hline AN-107 & 96 & & & & & & 96 \\
\hline AN-105 & 95 & & & & & & 95 \\
\hline SY-101 & 94 & & & & & & 94 \\
\hline AN-103 & 93 & & & & & & 93 \\
\hline$C-103$ & & 61 & & 31 & & & 92 \\
\hline$A W-101$ & 92 & & & & & & 92 \\
\hline$A W-105$ & & & & & 90 & & 90 \\
\hline $\mathrm{C}-106$ & & & 80 & & & & 80 \\
\hline$A P-103$ & & & 80 & & & & 80 \\
\hline AP- 107 & & & 80 & & & & 80 \\
\hline$A W-102$ & & & 80 & & & & 80 \\
\hline $5 x-103$ & & 75 & & & & & 75 \\
\hline$S X-101$ & & 74 & & & & & 74 \\
\hline U-106 & & 73 & & & & & 73 \\
\hline BY-106 & & 72 & & & & & 72 \\
\hline BY-105 & & 71 & & & & & 71 \\
\hline$U-108$ & & 70 & & & & & 70 \\
\hline AW-103 & 70 & & & & & & 70 \\
\hline$A W-104$ & 70 & & & & & & 70 \\
\hline U-107 & & 69 & & & & & 69 \\
\hline SY-103 & 69 & & & & & & 69 \\
\hline S-111 & & 68 & & & & & 68 \\
\hline$S X-102$ & & 67 & & & & & 67 \\
\hline$S-102$ & 67 & & & & & & 67 \\
\hline S-105 & 67 & & & & & & 67 \\
\hline S-103 & 67 & & & & & & 67 \\
\hline U-111 & & 66 & & & & & 66 \\
\hline S-101 & & 63 & & & & & 63 \\
\hline AN-101 & & & & & & 50 & 50 \\
\hline $\mathrm{AN}-106$ & & & & & & 50 & 50 \\
\hline$A P-102$ & & & & & & 50 & 50 \\
\hline A-101 & & & & 35 & & & 35 \\
\hline S-110 & & & & 35 & & & 35 \\
\hline$A X-103$ & & & & 35 & & & 35 \\
\hline$A X-101$ & & & & 34 & & & 34 \\
\hline BY -102 & & & & 33 & & & 33 \\
\hline BY-111 & & & & 33 & & & 33 \\
\hline$B Y-112$ & & & & 33 & & & 33 \\
\hline TX-112 & & & & 33 & & & 33 \\
\hline $\mathrm{C}-102$ & & & & 32 & & & 32 \\
\hline A-104 & & & & & & & 0 \\
\hline B-101 & & & & & & & 0 \\
\hline B-104 & & & & & & & 0 \\
\hline
\end{tabular}


RPP-6693 Rev. 0

Table A-1: Prioritization of Tanks for PCB Characterization

\begin{tabular}{|c|c|c|c|c|c|c|c|}
\hline Tank & Treatment & Saltwell & PCB Susp. & SST Retrleval & DST Recelver & Remaining DSTs & Total \\
\hline B-107 & & & & & & & 0 \\
\hline B-110 & & & & & & & 0 \\
\hline $8 X-101$ & & & & & & & 0 \\
\hline $\mathrm{BX}-104$ & & & & & & & 0 \\
\hline $\mathrm{BX}-107$ & & & & & & & 0 \\
\hline$B X-110$ & & & & & & & 0 \\
\hline BY-101 & & & & & & & 0 \\
\hline BY-104 & & & & & & & 0 \\
\hline BY-107 & & & & & & & 0 \\
\hline$B Y-110$ & & & & & & & 0 \\
\hline $\mathrm{C}-101$ & & & & & & & 0 \\
\hline$C-110$ & & & & & & & 0 \\
\hline S-104 & & & & & & & 0 \\
\hline $5 x-104$ & & & & & & & 0 \\
\hline SX-107 & & & & & & & 0 \\
\hline$S x-110$ & & & & & & & 0 \\
\hline$S x-113$ & & & & & & & 0 \\
\hline U-101 & & & & & & & 0 \\
\hline U-104 & & & & & & & 0 \\
\hline U-110 & & & & & & & 0 \\
\hline $\mathrm{T}-101$ & & & & & & & 0 \\
\hline$T-104$ & & & & & & & 0 \\
\hline$T-107$ & & & & & & & 0 \\
\hline$T-110$ & & & & & & & 0 \\
\hline TX-101 & & & & & & & 0 \\
\hline$T X-105$ & & & & & & & 인 \\
\hline$T X-109$ & & & & & & & 0 \\
\hline $\mathrm{TX}-113$ & & & & & & & 0 \\
\hline TX-116 & & & & & & & 0 \\
\hline TY-101 & & & & & & & 0 \\
\hline TY-103 & & & & & & & 0 \\
\hline TY-105 & & & & & & & 의 \\
\hline$A-102$ & & & & & & & 0 \\
\hline A-103 & & & & & & & 0 \\
\hline$A-105$ & & & & & & & 0 \\
\hline A-106 & & & & & & & 0 \\
\hline$A X-102$ & & & & & & & 0 \\
\hline$A X-104$ & & & & 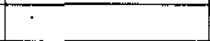 & & & 0 \\
\hline $\mathrm{B}-102$ & & & & & & & 0 \\
\hline B-103 & & & & & & & 0 \\
\hline$B-105$ & & & & & & & 0 \\
\hline$B-106$ & & & & & & & 0 \\
\hline B-108 & & & & & & & 의 \\
\hline $\mathrm{B}-109$ & & & & & & & 0 \\
\hline $\mathrm{B}-111$ & & & & & & & 0 \\
\hline $\mathrm{B}-112$ & & & & & & & 0 \\
\hline$B-201$ & & & & & & & 0 \\
\hline B-202 & & & & & & & 0 \\
\hline B-203 & & & & & & & 0 \\
\hline B-204 & & & & & & & 0 \\
\hline$B X-102$ & & & & & & & 0 \\
\hline $\mathrm{BX}-103$ & & & & & & & 0 \\
\hline$B X-105$ & & & & & & & 0 \\
\hline$B X-106$ & & & & & & & 0 \\
\hline$B X-108$ & & & & & & & 0 \\
\hline$B X-109$ & & & & & & & 0 \\
\hline$B X-111$ & & & & & & & 0 \\
\hline $\mathrm{BX}-112$ & & & & & & & 0 \\
\hline$B Y-103$ & & & & & & & 0 \\
\hline$B Y-108$ & & & & & & & 0 \\
\hline BY-109 & & & & & & & 0 \\
\hline$C-105$ & & & & & & & 0 \\
\hline $\mathrm{C}-108$ & & & & & & & 0 \\
\hline
\end{tabular}


RPP-6693 Rev. 0

Table A-1: Prioritization of Tanks for PCB Characterization

\begin{tabular}{|c|c|c|c|c|c|c|c|}
\hline Tank & Treatment & Saltwell & PCB Susp. & SST Retrieval & DST Recelver & Remaining DSTs & Total \\
\hline C-109 & & & & & & & 0 \\
\hline C-111 & & & & & & & 0 \\
\hline $\mathrm{C}-112$ & & & & & & & 0 \\
\hline C-201 & & & & & & & 0 \\
\hline C-202 & & & & & & & 0 \\
\hline C-203 & & & & & & & 0 \\
\hline C-204 & & & & & & & 0 \\
\hline SX-105 & & & & & & & 0 \\
\hline$S X-106$ & & & & & & & 0 \\
\hline SX-108 & & & & & & & 0 \\
\hline SX-109 & & & & & & & 0 \\
\hline$S X-111$ & & & & & & & 0 \\
\hline $5 x-112$ & & & & & & & 0 \\
\hline$S x-114$ & & & & & & & 0 \\
\hline$S X-115$ & & & & & & & 0 \\
\hline $\mathrm{U}-102$ & & & & & & & 0 \\
\hline U-103 & & & & & & & 0 \\
\hline U-105 & & & & & & & 0 \\
\hline $\mathrm{U}-109$ & & & & & & & 0 \\
\hline U-112 & & & & & & & 0 \\
\hline U-201 & & & & & & & 0 \\
\hline $\mathrm{U}-202$ & & & & & & & 0 \\
\hline U-203 & & & & & & & 0 \\
\hline \begin{tabular}{|l|}
$U-204$ \\
\end{tabular} & & & & & & & 0 \\
\hline $\mathrm{T}-102$ & & & & & & & 0 \\
\hline $\mathrm{T}-103$ & & & & & & & 0 \\
\hline $\mathrm{T}-105$ & & & & & & & 0 \\
\hline$T-106$ & & & & & & & 0 \\
\hline$T-108$ & & & & & & & 0 \\
\hline $\mathrm{T}-109$ & & & & & & & 0 \\
\hline$T-111$ & & & & & & & 0 \\
\hline $\mathrm{T}-112$ & & & & & & & 0 \\
\hline $\mathrm{T}-201$ & & & & & & & 0 \\
\hline $\mathrm{T}-202$ & & & & & & & 0 \\
\hline $\mathrm{T}-203$ & & & & & & & 0 \\
\hline$T-204$ & & & & & & & 0 \\
\hline $\mathrm{TX}-102$ & & & & & & & 0 \\
\hline TX-103 & & & & & & & 0 \\
\hline$T X-104$ & & & & & & & 0 \\
\hline TX-106 & & & & & & & 0 \\
\hline$T X-107$ & & & & & & & 0 \\
\hline $\mathrm{TX}-108$ & & & & & & & 0 \\
\hline TX-110 & & & & & & & 0 \\
\hline$T X-111$ & & & & & & & 0 \\
\hline $\mathrm{TX}-114$ & & & & & & & 0 \\
\hline $\mathrm{TX}-115$ & & & & & & & 0 \\
\hline $\mathrm{TX}-117$ & & & & & & & 0 \\
\hline $\mathrm{TX}-118$ & & & & & & & 0 \\
\hline TY-102 & & & & & & & 0 \\
\hline TY-104 & & & & & & & 0 \\
\hline TY-106 & & & & & & & 0 \\
\hline
\end{tabular}


DISTRIBUTION SHEET

\begin{tabular}{|c|c|c|c|c|c|c|}
\hline \multirow{2}{*}{ To $\quad$ Distribution } & \multirow{2}{*}{\multicolumn{3}{|c|}{ Process Control }} & \multicolumn{3}{|c|}{ Page 1 of 1} \\
\hline & & & & \multicolumn{3}{|c|}{ Date } \\
\hline \multicolumn{4}{|c|}{ Project Title/work Order } & \multicolumn{3}{|c|}{ EDT No. EDT-628395 } \\
\hline \multicolumn{4}{|c|}{$\begin{array}{l}\text { RPP-6693, Rev. 0, "Characterization Plan for Establishing a PCB } \\
\text { Baseline Inventory in Hanford Waste Tanks" }\end{array}$} & \multicolumn{3}{|c|}{ ECN No. N/A } \\
\hline \multicolumn{2}{|l|}{ Name } & $\begin{array}{c}\text { Text } \\
\text { With } \\
\text { All } \\
\text { Attach. }\end{array}$ & Text only & & $\begin{array}{l}\text { Attach./ } \\
\text { Appendix } \\
\text { Only }\end{array}$ & $\begin{array}{l}\mathrm{EDT} / \mathrm{ECN} \\
\text { Only }\end{array}$ \\
\hline
\end{tabular}

CH2M Hill Hanford Group, Inc.

D. L. Banning

C. DeFigh-Price

W. T. Dixon

B. G. Erlandson

J. G. Field

M. D. Hasty

J. W. Hunt

N. W. Kirch

J. A. Lechelt

S. G. McKinney

C. H. Mulkey

D. M. Nguyen

G. L. Parsons

M. J. Sutey

G. A. Stanton

D. J. Washenfelder

T.C.S.R.C.

$\begin{array}{ll}R 2-12 & X \\ R 2-12 & X \\ R 1-51 & X \\ R 1-51 & X \\ R 2-12 & X \\ S 7-01 & X \\ R 2-12 & X \\ R 2-11 & X \\ R 2-11 & X \\ R 2-12 & X \\ R 1-51 & X \\ R 2-12 & X \\ R 3-47 & X \\ \text { S5 }-07 & X \\ \text { S7 }-01 & X \\ \text { H6 }-18 & X \\ \text { R1 } 10 & X\end{array}$

CH2MHill Incorporated

L. M. Johnson

H9-01 $\mathrm{X}$

Numatec Hanford Corporation

J. S. Garfield

R3-73 X

Waste Management Hanford

C. M. Seidel

G1-32 X 